\title{
The Influence of Gratitude on Psychological Resilience of Adolescence Living in Youth Social Care Institutions
}

\author{
Ratih Arruum Listiyandini \\ Faculty of Psychology, Universitas YARSI \\ ratih.arruum@yarsi.ac.id
}

\begin{abstract}
This study aims to determine the role of gratitude on psychological resilience of adolescents who live in youth social care institutions (orphanages). The study was conducted using a quantitative cross-sectional design. The population of the study was adolescents who lived at youth social care institutions in Jakarta and Bekasi. Two hundred samples were obtained by convenience sampling. The researcher used the Indonesian version of gratitude scale and an adapted resilience scale as measurement tools. Regression analysis found that gratitude explains 13.I percent variance of adolescences' psychological resilience. The role of gratitude toward psychological resilience is positive, indicating that higher gratitude reflect higher resilience. Therefore, gratitude needs to be considered in the development of resilience program for adolescents living in youth social care institutions.
\end{abstract}

Keywords: adolescence, gratitude, orphanages, resilience, social care.

Received I5 August2018/Accepted 29 November 2018 @ JEHCP All rights reserved

\section{Introduction}

Parental engagement is an important factor in the lives of adolescents. During this period, adolescents often experience psychological difficulties (Santrock, 2008), highlighting the need for parental guidance in times of identity confusion and adjustment to adulthood. In fact, some adolescents are mentored by their parents throughout their entire life. However, various reasons could also force adolescents to live apart from their family (e.g., low economic background, being orphaned). These adolescents must live under youth social care institutions (Hartini, 200I).

Adolescents living at youth social care institutions

Youth social care center (orphanages), a social welfare institution, provides services to meet the physical, mental, and social needs of foster children (Depsos RI in Armis, 2016). According to the Indonesian Ministry of Social Affairs in 2008, the estimated number of 
orphanages in Indonesia range from 5,000 - 8,000 orphanages. These houses are up to half a million children. Non-government communities, particularly religious organizations, created more than $99 \%$ of these orphanages. Around $90 \%$ of the residents in social care services have one or both parents and only roughly $6 \%$ are truly orphans. Most children are placed in institutions to ensure that they receive an education despite having economic difficulties (Depsos RI in Armis, 2016).

There are several psychosocial challenges that present itself in youth social care services. The limited number of caregivers causes a lack of emotional support. Orphanage received less compassion, attention, and in-depth guidance, as well as showed a decrease in academic achievement (Yendork \& Somhlaba, 20I4). Yildirim (Gursoy et al, 20I2) revealed that physical conditions in orphanages, lack of guidance, community stigma, and lack of family support can negatively impact children in orphanages. It was found that adolescent living in institution has a higher level of depression compared to adolescents living at home (Wuon, Bidjuni, \& Kallo, 2016). Previous study conducted by Fabrykowski and Piver (in Nurindah, Afiatin, \& Sultyarini, 2012) showed that they have characteristics caused by trauma and neglect by their families including self-blame, feeling powerless, low optimism, feeling like a lost, betrayed, and abandoned child. Hartini (200I) also found that adolescent who resides in a youth care institution are more inferior, passive, apathetic, withdrawn, easily discouraged, fearful, and anxious compared to those living with family members.

\section{Psychological resilience}

Although some psychological vulnerability exists in adolescents living in youth care institutions, some demonstrate the capacity to rise up from various challenges. Based on our preliminary studies using questionnaires and interviews in one of the orphanages in Bekasi, $80 \%$ of orphanage adolescents are happy to help others and satisfied with their current condition. These prosocial behavior and positive outlook to life indicate that teenagers who live in institution are also able to show adaptive psychological functioning, their difficult circumstances.

The ability of individuals to survive, overcome, and develop under difficulties is called resilience (Connor \&Davidson, 2003). Connor and Davidson (2003) stated that resilience 
can also be seen as a successful stress coping ability. Resilient individuals have several personal characteristics, such as being resistant to stress, and having good emotional regulation, flexibility to accept changes, close relationships with others, and self-control (Reivich \& Shatte, 2002; Connor \&Davidson, 2003).

With those characteristics, resilient individuals will have the capacity to respond adaptively and productively in the face of challenges (Reivich \& Shatte, 2002). Previous research shown that resilient adolescents will have better mental health, including lower depressive symptoms (Mujahidah \& Listiyandini, 2018). In the context of adolescents in institutions, resilience allows them to cope with various stresses and ultimately avoid psychological distress that can could negatively impact their mental and physical health. Thus, it is crucial to examine factors related to psychological resilience of adolescents living in institutions.

There are several factors that relates to resilience of young people, such as personality (Sidik \& Listiyandini, 20I7), character strength (Listiyandini \& Akmal, 20I5), optimism (Roellyana \& Listiyandini, 2016), social intelligence (Andriani \& Listiyandini, 2017), self-compassion (Febrinabilah \& Listiyandini, 20I6) parenting style (Permata \& Listiyandini, 20I5), and social support (Tricahyani \& Widiasavitri, 2016, Khabbaz., Behjati \& Naseri, 2012). Other factors that found to have relation with mental health and well-being of adolescents is mindfulness which found related with lower depressive symptoms (Fourianalistyawati \& Listiyandini, 2018) and psychological well-being (Savitri \& Listiyandini, 2017) among adolescents. However, beyond these factors, we are interested in examining another internal factor that comes from within the individual namely gratitude.

\section{Gratitude as protective factor for mental health}

According to Peterson and Seligman (2004), gratitude is the feeling of being grateful and happy in response to a gift, whether tangible or intangible. Gratitude is also interpreted as a feeling of joy and thankfulness in response to acceptance of goodness (McCullough, Tsang, \& Emmons, 2004). As an emotion, this character strength occurs in the form of amazement and appreciation for life itself (Seligman, 2005). 
Gratitude allows individuals to perceive suffering as a source for positive life lessons. Thus, individuals will be able to, both consciously and unconsciously, improve their coping skills which also triggers the emergence of self-meaning that leads people to positive direction (Mc Millen in Krause, 2006) In the context of adolescents living in youth care services, gratitude is needed to aid them in interpreting their lives positively even in difficult situations. An institutional teenager who has gratitude will appreciate all the good they have received; thus they will have a more positive perspective in life. Listiyandini (2016) previously found that resilience in the younger generation can be predicted by the gratitude they have.

\section{Purpose of this current study}

Although previous research showed that gratitude can bring benefit for the mental health of individuals, the role of gratitude towards resilience has not been expanded to include adolescents living in orphanages. This could contribute in the improvements of community mental health. Thus, we aim to examine whether gratitude can predict the psychological resilience of adolescents living in youth social care institutions.

It is predicted that gratitude can assist adolescents in orphanages to accept and respect their current situation and improve their perspective about life. This will in turn ignite positive emotion and adaptive coping styles in addressing various existing problems in their daily life. In other words, we hypothesized that gratitude has a significant positive role in shaping the resilience of adolescents in youth social care institutions.

\section{Method}

\section{Participants}

Participants were adolescents who lived in social care institutions in the area of Jakarta and Bekasi. The inclusive criteria are: age between II-I8 years old, lives permanently in youth care institutions, able to read and write, and willing to participate in this study. We do not specify the criteria based on gender or reason for living in youth care institutions because this is an explorative study. In other words, the participants include both adolescent who are orphaned and those who enter the institution purely due to economic condition. 
The number of sample obtained in this study was 200 adolescents. It consists mostly of males (50.5\%) with a mean age of 14.77. Based on their responses, we found that the main reason for staying at the institution was economic conditions (58\%), being orphaned (37\%), and other reason such as being a street child (5\%). Most orphanages are religion-based institutions, especially Islam (81\%) and only around 15\% are not religion-based. Additionally, most adolescents who lives in orphanage also considered their friends (58.5\%) to be their closest support group.

\section{Design and Procedure}

This is a cross-sectional quantitative study. In other words, we evaluated the influence of gratitude toward psychological resilience by taking the data once, at a set period of time, using questionnaires. Samples were taken by convenience sampling technique, where the researcher visited orphanages in the Jakarta and Bekasi area due to accessibility. The study was approved by the Research Ethics Committee of YARSI University. Further, all participants signed an informed consent prior to filling in the questionnaires.

We adapted the research instruments through back-to-back translation process, including testing for feasibility test, before data collection. Next, we identified available youth care institutions from the internet (e.g., government agency web) and contacted them individually to set an appointment for data collection. There were 12 youth care institutions that were willing to participate in this study. Data collection was conducted from NovemberDecember 2017 by our researcher and assistant.

\section{Instruments}

Resilience was measured using a uni-dimensional scale, adapted and modified from the resilience scale by Connor and Davidson (2003). This 5-point Likert-scale consists of 25 items. The samples of items are "Saya pantang menyerah ketika segala sesuatu tampak tidak ada harapan [When things look hopeless, I don't give up]" and "Saya tidak mudah putus asa dalam kegagalan [I am not easily discouraged by failure]. Higher score indicates higher level of psychological resilience. The reliability and validity of the instruments for adolescents has been tested from previous research (see Mujahidah \& Listiyandini, 2018). The reliability test 
of the instrument in the adolescent population was found to have a value of $\alpha=.89$, with the corrected item-total correlation score above 0.2 , indicating adequate reliability and validity.

To measure gratitude, we used an Indonesian version of the gratitude scale which was developed by Listiyandini, et.al. (2015). The Indonesian gratitude scale is a uni-dimensional scale, consisting of 30 items. It is a 6-point Likert scale. Samples of the items include "Ketika saya menerima suatu karunia, saya langsung mengucapkan pujian kepada Tuhan [When I receive a gift, I immediately praise God]" and "Saya merasa beruntung telah dilahirkan di dunia ini [I feel fortunate to have been born in this world]". Higher scores reflect a higher level of gratitude. The reliability coefficient is $\alpha=.88$ (Listiyandini, et.al, 20I5).

\section{Data Analysis}

We used simple regression to analyze the data with the aid of the SPSS 23.0 for Windows. The predictor variable is the total score of gratitude, while the criterion variable is the total score of resilience.

\section{Results}

Descriptive statistic

The results show that the distribution of the resilience score ranges from 3-97 $(M=66.94$, $S D=14.067)$. Meanwhile, the range for the gratitude score is $96-170(M=141.88, S D=$ 15.55). Normality and linearity tests show that the residual data distribution from both variables are normally distributed $(\mathrm{K}-\mathrm{Sz}=.042, \mathrm{p}=.200)$. Both variables show a linear relationship $(r=.362, p=.000)$.

Additionally, we conducted a preliminary analysis to identify the association between resilience with gender, age, or type of orphanages. Our finding reveals that there is no significant difference in the level of resilience based on gender or type of orphanage. However, we found that there is a significant difference in the level of resilience based on age, with older adolescents $(16-18$ years old) showing higher resilience $(\mathrm{MI}=69.99)$ than younger adolescents $(M 2=64.37)(t=2.792, p=.006)$. 
Main finding: The influence of gratitude toward psychological resilience

Regression was conducted to analyze the role of gratitude towards resilience in participants. Simple regression analysis shows that gratitude score can significantly explain $13.1 \%$ of the variance of resilience $\left(R^{2}=.131, F=29.898, p=0.000\right)$. We also found that gratitude plays a significant positive role $(b=9,826, p=0.000)$ in the resilience of adolescent living in social care institutions (see Table I):

Table I

Gratitude as Predictor of Psychological Resilience

\begin{tabular}{ccc}
\hline Variable & \multicolumn{2}{c}{ Psychological Resilience } \\
\cline { 2 - 3 } & $\mathrm{B}(\mathrm{SE})$ & $\mathrm{P}$-value $(95 \% \mathrm{Cl})$ \\
\hline Constant & $20.064(8.550)$ & 0.020 \\
Gratitude & $9.826^{* *}(1.791)$ & 0.000 \\
$\mathrm{R}^{2}$ & .131 & \\
$\mathrm{~F}$ & $29.898^{* *}$ \\
\hline Note. $\mathrm{N}=200$. Cl=confidence interval. ${ }^{* *} \mathrm{p}<0.01$
\end{tabular}

\section{Discussion}

The results show that gratitude plays a significant positive role in explaining the resilience of adolescents living in youth care institutions. It suggests that grateful adolescents will thrive more in the face of adversity compared to those who are ungrateful. The effective contribution of gratitude towards resilience in this study (13.1\%), is much higher than the finding from a previous study on college students (II\%) (Listiyandini, 20l6).

In general, resilience is very important for adolescents because the social, biological, and psychological changes that adolescents experience require them to be adaptive in dealing with problems (Khabbaz., Behjati \& Naseri, 2012; Athigi., Athigi \& Atighi, 2015). For adolescents living in orphanages, resilience is important in helping them rise from unwanted reality or depressing conditions (e.g., losing parents, economic problems) allowing them to live more productively. Ideally, adolescents should develop relatively similar cognitive, 
emotional, and social abilities regardless of their living situation (Fadhillah, Uyun, \& Sulistiyarini, 2017). In this study, gratitude was found to be an important role for building resilience in adolescents living in youth care institutions.

Gratitude will cultivate adolescents' ability to be more appreciative to what they have, allowing them to produce more positive feelings. Empirically, positive emotion can increase emotional resources such as welfare and resilience (Fredrickson, 200I). In turn, it could aid adolescents in seeking better problem-solving strategies and maintain a positive mindset in the face of various challenges. Gratitude will help them bounce back from negative situations by introducing a different perspective when social and psychological pressures become overwhelming. The positive role of gratitude toward resilience is in line with the research conducted by Bono, Emmons, and McCullough (2004) which shows that being grateful can prevent depressive and pathological conditions. Watkins, et.al (2003) also stated that gratitude can indicate the level of well-being of the individuals.

In addition, the role of gratitude toward psychological resilience of orphanages can also be explained by social perspective. McCullough, Tsang \& Emmons (2004) state that grateful individual will feel supported by others. In the case of grateful orphanage adolescents, they tend to be more expressive in showing their appreciation to others and willing to help others as an expression of their gratitude. As suggested by Froh, Yurkewicz, \& Kashdan (2009), grateful adolescents tend to have better peer support because gratitude gives them joy that increases their willingness to do activities together with friends. This pro-social action, a part of gratitude, can bring higher social connection among orphanages and other people. Social connection itself is needed for individuals to be more resilience, where they can rely on their friend during difficult situations (Saichu \& Listiyandini, 2018).

Furthermore, the study found that late adolescents had a significantly higher resilience compared to early adolescents. These results are in line with Freisen (2005) who suggested that older individual have more mature abstract thinking and experience, allowing them to produce better solutions to problem. In this current study, it can be explained that if orphanage adolescents getting more mature, they can solve problem more effectively when 
facing difficulties. Thus, they will be able to be more adaptive and resilient during challenging situation.

During this study, several limitations still existed. The respondents mostly came from lower socio-economic background and we did not specialize in orphanage teenagers with significant conditions of traumatic experience (e.g., suffers from the lost of both parents). Different sample characteristics could be produce different results in subsequent studies. In addition, this study did not explain about the mediating factor between gratitude and resilience. Our finding only explain that gratitude can be an important factor for orphanage adolescents to thrive in the face of adversity during their life.

\section{Conclusion}

The results show that gratitude plays a significant role in explaining resilience among adolescents living in youth social care institutions. The relation is positive, meaning that higher level of gratitude reflects higher resilience. Gratitude allows adolescents who live in institutions to thrive better in the face of various problems.

Based on our findings, we suggest that resilience programs be made for adolescents who live in orphanages. This can be done by providing training and activities that enhance gratitude, such as writing a gratitude journal starting from documenting three good things that occur each day. Additionally, future studies should aim to identify mediating factors between gratitude and resilience and examine external protective factors that could affect psychological resilience (e.g., peers and teacher support, emotional regulation).

\section{Acknowledgement}

This work was funded by the 2017 YARSI Research Grant. Appreciation is given for a team of research assistants, Annisa Zahra Kawitri, Bellatrix Dwi Rachmawati, and Santri Wijayanti who aided in data collection. 


\section{References}

Andriani, A., \& Listiyandini, R. A. (2017). Peran kecerdasan social terhadap resiliensi pada mahasiswa tingkat awal. (The role of social intelligence toward resilience of first year college students). Psympathic: Jurnal Ilmiah Psikologi, 4(I), 67-90.

Armis, A. (2016). Manajemen panti asuhan at-taqwa muhammadiyah dalam membina kepribadian siswa MTS Muhammadiyah Padang Luar Kecamatan Rambatan Kabupaten Tanah Datar (The management of At-Taqwa Muhammadiyah on building personality of students in MTS Muhammadiyah Padang Luar Kecamatan Rambatan Kabupaten Tanah Datar). Al-Fikrah, 3(2), I37-I46.

Atighi, E., Atighi, A., \& Atighi, I. (20I5). Predicting psychological resilience based on parenting styles in girl adolescence. International Research Journal of Applied and Basic Sciences, 9(8), I340-1344.

Bono, G., Emmons, R.A., \& McCullough, M.E. (2004). Gratitude in practice and the practice of gratitude, dalam Linley, A.P. dan Joseph, S.(editor), Positive Psychology in Practice, 464477. New Jersey: John Willey dan Sons, Inc.

Connor, K. M. \& Davidson, J.R.T. (2003). Development of a new resilience scale: The connor-davidson resilience scale (CD-RISC). Depression and Anxiety, I8, 76-82.

Fadhillah, A. R., Uyun, Q., \& Sulistyarini, I. (2017). Pengaruh terapi kognitif perilaku berbasis kekuatan terhadap peningkatan resiliensi pada remaja panti asuhan. (The effectiveness of cognitive behavioral therapy for improving resilience on adolescence orphanage). Jurnal Intervensi Psikologi, 9(I), 96-I06.

Febrinabilah, R., \& Listiyandini, R. A. (2016). Hubungan antara self-compassion dengan resiliensi pada mantan pecandu narkoba dewasa awal. (The relationship between selfcompassion and resilience among early adult whose being former drug addicts). Prosiding Konferensi Nasional Peneliti Muda Psikologi Indonesia, I ( I), 19-28.

Fredrickson, B.L. (200I). The role of positive emotions in positive psychology: The broaden and build theory of positive emotions. The American Psychologist, 56(3), 218-226.

Freisen, B. J. (2005). Resilience and recovery: Findings from thelongitudinal study. Research, Policy, and Practice in Children's Mental Health Summer, I9(I), II-I4.

Froh, J. J., Yurkewicz, C., \& Kashdan, T. B. (2009). Gratitude and subjective well-being in early adolescence: Examining gender differences. Journal of Adolescence, 32, 633-650.

Fourianalistyawati, E., \& Listiyandini, R. A. (20/8). Hubungan antara mindfulness dengan depresi pada remaja. (The relationship between mindfulness and depression among adolescents). Journal Psikogenesis, 5(2), II5-I22.

Gursoy, F., Bicakci, M.Y., Orhan, E., Bakirci, S., Catak, S., \&Yerebakan, O. (2012). Study on self-concept levels of adolescents in the age group of $13-18$ who live in Orphanage and 
those do not live in Orphanage. International Journal of Social Sciences and Education, 2(I), 56-66.

Hartini, N. (200I). Deskripsi kebutuhan psikologi pada anak panti asuhan. (Psychological needs profile of children living at orphanage). Insan Media Psikologi, 3(2), I09-I I8.

Khabbaz M., Behjati Z., \& Naseri, M. (2012). Relationship between social support and coping style and resiliency in adolescent. Journal of Applied Psychology, 5(4), I08- 23.

Krause, N. (2006). Gratitude toward god, health, and stress in late life.Research in Aging,28 (2), 163. http://proquest.umi.com/pqdweb.

Listiyandini, R. A., Nathania, A., Syahniar, D., Sonia, L., \&Nadya, R. (2015). Mengukur rasa syukur: Pengembangan model awal skala bersyukur versi Indonesia. (Measuring gratitude: Early development model of the Indonesia gratitude scale version). Jurnal Psikologi Ulayat: Indonesian Journal of Indigenous Psychology, 2(2), 473-496.

Listiyandini, R. A. (2016). Tangguh karena bersyukur: bersyukur sebagai afek moral yang dapat memprediksi resiliensi generasi muda. (Resilience because of gratitude: gratitude as a moral affect that can predict the resilience of young generation). Prosiding Seminar Nasional Universitas Merdeka Malang, downloaded from researchgate.net.

Listyandini, R. A., \& Akmal, S. A. (20I5). Hubungan antara kekuatan karakter dan resiliensi pada mahasiswa. (The relationship between character strength and resilience among college students). Prosiding Temu Ilmiah Nasional Psikologi. Jakarta: Fakultas Psikologi Universitas Pancasila, downloaded from researchgate.net.

McCullough, M.E., Tsang, J. \& Emmons, R.A. (2004). Gratitude in intermediate affective terrain: Links of grateful moods to individual difference and daily emotional experience. Journal of Personality and Social Psychology, 86, 295-309.

Mujahidah, E., \& Listiyandini, R. A. (2018). Pengaruh resiliensi dan empati terhadap gejala depresi pada remaja (The influence of resilience and empathy toward depression among adolescents). Jurnal Psikologi, I4(I), 60-75.

Nurindah, M., Afiatin, T., \& Sulistyarini, I. (20I2). Meningkatkan optimisme remaja panti sosial dengan pelatihan berpikir positif. (Increasing optimism among social institution adolescent with positive thinking training). Jurnal Intervensi Psikologi, 4(I), 57-76.

Permata, D. C., \& Listiyandini, R. A. (20I5). Peranan pola asuh orang tua dalam memprediksi resiliensi mahasiswa tahun pertama yang merantau di Jakarta. (The role of parenting style in predicting the resilience of first-year migrate students in Jakarta). Prosiding PESAT.

Peterson, C., \& Seligman, M.E.P. (2004). Character strength and virtues: A handbook \& classification. New York: Oxford University Press. 
Reivich, K. \& Shatte, A.(2002). The Resilience Factors. New York: Broadway Books.

Roellyana, S., \& Listiyandini, R. A. (2016). Peranan optimisme terhadap resiliensi pada mahasiswa tingkat akhir yang mengerjakan skripsi. (The role of optimism towards resilience among final year students who doing thesis). Prosiding Konferensi Nasional Peneliti Muda Psikologi Indonesia.

Saichu, A. C., \&Listiyandini, R. A. (2018).Pengaruh dukungan keluarga dan pasangan terhadap resiliensi ibu yang memiliki anak dengan spectrum autism. (The influence of family and partner support towards the resilience of mothers with autism spectrum children). Psikodimensia, I 7(I), I-9.

Savitri, W. C., \& Listiyandini, R. A. (2017). Mindfulness dan Kesejahteraan Psikologis pada Remaja. (Mindfulness and psychological Well-being of Adolescents). Psikohumaniora: Jurnal Penelitian Psikologi, 2(I), 43-59.

Santrock. (2008). Life span development. II thed. New York: McGraw Hill.

Seligman, M. E. P. (2005). Authentic happiness: Using the new positive psychology to realize your potential for lasting fulfillment. New York: Free Press.

Tricahyani, I. A. R., \&Widiasavitri, P. N. (2016).Hubungan antara dukungan sosial dengan penyesuaian diri pada remaja awal di panti asuhan kota Denpasar. (Relationship between social support and personal adjustment among early adolescents in orphanage at Denpasar city). Jurnal Psikologi Udayana, 3(3), 542-550.

Watkins, P.C., Woodward, K., Stone T., \& Kolts, R.L. (2003). Gratitude and happiness: Development of a measure of gratitude, and relationships with subjective well-being. Social Behavior and Personality, 31 (5), 431-452. Retrieved from www.ProQuest.com. (Document ID: 4209428II).

Wuon, A. S., Bidjuni, H., \& Kallo, V. (2016).Perbedaan tingkat depresi pada remaja yang tinggal di rumah dan yang tinggal di panti asuhan Bakti Mulia Karombasan Kecamatan Wanea Manado (Differences in the levels of depression among teenager living at home and living in an orphanage Bakti Mulia Karombasan District Wanea Manado). Jurnal Keperawatan, 4(2), I-8.

Yendork, J. S., \& Somhlaba, N. Z. (20I4). Stress, coping and quality of life: An exploratory study of the psychological well-being of Ghanaian orphans placed in orphanages. Children and Youth Services Review, 46, 28-37. 